\title{
La participación de la sociedad civil en la gestión del bien común: un caso en la ética de los centros de recursos biológicos
}

\author{
Civil society participation in the management \\ of the common good: a case of ethics in biological \\ resource centres
}

PATRICI CALVO and STEFAN ERIKSSON

UNIVERSITAT JaUME I and UPPSALA UNIVERSITY

\begin{abstract}
The management of commons is now at the centre of researchers' attention in many branches of science, particularly those related to the human or social sciences. This paper seeks to demonstrate how civil society participation in common goods or resources is not only possible but is also desirable for society because of the medium and long-term benefits it offers involved and/or affected parties. To this end, we examine the falsity of the discourse underlying the supposed incompetence of civil society to cooperate interpersonally in the pursuit of common objectives, and also analyse a specific example of the necessary and possible participation of civil society in managing common goods through biobanks.
\end{abstract}

Keywords: civil society, common godos, biobanks, ethical management.

\section{Resumen}

La gestión del bien común se ha convertido actualmente en centro de atención para diferentes ramas de la ciencia, especialmente aquellas vinculadas con lo humano y lo social. El presente estudio busca mostrar cómo la participación de la sociedad civil en la gestión de este tipo de bienes o recursos no sólo es posible, sino deseable para la sociedad por los beneficios que reporta a las partes implicadas y/o afectadas a medio y largo plazo. Para ello, se atenderá la falsedad del discurso sobre el cual se asienta la supuesta incompetencia de la sociedad civil para poder cooperar interpersonalmente en busca de objetivos comunes, así como se analizará un ejemplo concreto de la necesaria y posible participación de la sociedad civil en la gestión del bien común a través de los centros de recursos biológicos (BRCS).

Palabras clave: sociedad civil, bien común, biobancos, gestión ética. 
Studies into the concept and social role of the common -not publicgood can be traced back to the classical period and continue today. From Plato to John Stuart Mill, by way of Aristotle, St Thomas of Aquino, Niccolò Machiavelli, Erasmus of Rotterdam, Thomas Hobbes and Antonio Genovesi, among others: all have theorised on the question, drawing connections with governance, morality, happiness, peace, excellence or laws.

In recent decades, concern over the inefficiency of the markets, the overexploitation of natural ecosystems, the political disaffection of democratic societies and the unsustainability of the welfare state has brought the management of common goods to the forefront of attention for many thinkers in their respective areas of knowledge, particularly in disciplines related to the human and social sciences. Political scientists such as Elinor Ostrom and Carole J. Uhlaner, economists like Stefano Zamagni, Oliver E. Williamson and Christian Felber, the sociologists Pierpaolo Donati, Renate Mayntz and Wolgang Hofkirchner and philosophers such as Jacques Maritain and Martha Nussbaum, for example, have undertaken research at varying levels on the concept of and the best ways of managing common goods in different spheres of human activity. Among other issues, most of these scholars stress the need to foster civil society participation in managing the common good; on the one hand, because defining a society's common good and legitimating its management does not depend on governments, but on the intersubjective agreement of all those affected by it; and on the other hand, because managing the common good efficiently and sustainably requires collective actions of a society's citizens and organisations, as has been clearly reflected in case studies (Cárdenas and Ostrom, 2004; Ostrom, 1990, 2002; Ostrom and Nagendra, 2010).

Today, however, despite the studies and empirical evidence, the tendentious discourse still persists on the supposed incapacity of civil society to manage a common good efficiently and sustainably, arguing that the only possible solution to ensure its survival is by turning it into a public or private good. Issue 15 of Recerca. Revista de Pensament $i$ Anàlisis makes a significant contribution in this regard, by exploring the falsity of this nineteenthcentury discourse and highlighting the cooperative and coordinating competences of civil society to meet common objectives through collective actions of various kinds in both politics and the economy. This special issue is part of the research project «Ética de la democracia: crisis de la política y nuevas formas de participación de la sociedad civil», [P1.1B2013-24], funded by Universitat Jaume I of Castelló.

This article sets out to introduce the contributions in this monographic issue of Recerca. Revista de Pensament i Anàlisis on «Managing the common 
good: new forms of civil society participation in politics and the economy». The main aim of this issue is to bring to light the possibilities of interpersonal and intergroup cooperation in the different spheres of human activity, by clarifying both the theoretical framework of these arguments and by exploring a practical case in the form of biological resource centres (BRCS).

\section{THE POSSIBILITY OF COOPERATION}

In 1968, the ecologist Garrett Hardin metaphorically imagined the tragedy underlying the situation of a society that leaves the management of its common goods or resources in the hands of its individuals or associations. Based on one of the axioms of economic theory -the supposed propensity of individuals to maximise their own gain-, he predicted the point of no return that all collective action processes lead to if they are not coordinated by an external institution with the capacity to generate binding norms and apply coercive laws, namely, the overexploitation of limited resources and their irreversible disappearance.

Thus, Hardin put forward two worrying and unsolvable questions. First, that every attempt civil society makes to coordinate action to manage a particular common good or resource, be it a forest, a river basin, pasture land, a sea or an urban habitat, is futile without the help of external coercion that obliges the parties involved to respect the agreements reached.And second, that relying on the capacity of agents to cooperate and coordinate the action inevitably leads to the extinction of the managed common good or resource.

As the author himself clarifies, this is the drama that hangs over individuals because of their natural propensity to selfishness, since their incapacity to interrelate and coordinate with other agents in pursuit of a common objective becomes an insurmountable snare, any attempt to avoid which inexorably ends in a tragedy for humanity:

[...] Therein is the tragedy. Each man is locked into a system that compels him to increase his herd without limit-in a world that is limited. Ruin is the destination toward which all men rush, each pursuing his own best interest in a society that believes in the freedom of the commons. Freedom in a commons brings ruin to all (Hardin, 1968: 1244).

The problem, therefore, lies in the impossibility that those involved will cooperate to find a mutually beneficial outcome, such as the efficient management of the common good or resource. Hardin, therefore advocates a solution external to civil society that prevents or controls all forms of par- 
ticipation in the common good or resource: privatise it, make it public or regulate it.

1. Turn it into private property: in this way access to and use of these commons are restricted, allowing them to be efficiently managed and preventing the resource from running out. Hardin recognises that private property is not a just solution, but, in his words, «injustice is preferable to total ruin» (1968: 1247).

2. Turn it into public property: state management can also ensure restriction of access to and use of the common and, therefore, its long-term efficiency and durability (1968: 1245). Hardin seemingly understands that this would restrict the freedom to use the common, but as he states, establishing "an alternative to the commons need not be perfectly just to be preferable» (1968: 1247).

3. Regulate it with external coercion: the state government ensures the sustainability of resources with common usage through laws that impose sanctions on those who infringe them (1968: 1247-1248). Again, as in the above cases, the solution is linked to the restriction of use and appropriation by all or many of those affected.

These three possible solutions to the 'tragedy of the commons' put forward in the paper of the same name expose a lack of trust in the capacities and possibilities of civil society to efficiently manage the common goods or resources on which its activity, survival and happiness depend. However, how agents and organisations actually behave is a long way from what Hardin describes in his sombre and pessimistic paper. In most occasions observed, players cooperate with other participants in, for instance, economic or political contexts where the great majority of participants regard this as a desirable attitude (Bowles and Gintis, 2011; Ferh et al., 2002; Gintis et al., 2005; Cárdenas and Ostrom, 2004).

Game theory, for example, has achieved forms of cooperation based on the perfect and complete rationality that supposedly underlies all responses of the economic agent. Although it does not seem very likely, due to the selfinterested nature of the participants in strategy games, through equilibria -as a set of pure strategies, each one of which is the optimum strategy for each participant when the decisions of the other players are taken into account- the mathematician John F. Nash distanced himself from this idea by showing how and why cooperation can be achieved among people who are merely concerned to maximise their personal gain (1950a, 1950b).

The political scientist Elinor Ostrom later applied these same equilibria to demonstrate that not only was it possible to cooperate in a self-interested 
way to achieve one's own objective, sub-optimum in any event, but that the agents use feelings and the prosocial emotions that underlie them to generate interpersonal relationships with their peers with which they can meet common objectives efficiently (Ostrom, 2003; Ostrom and Ostrom, 2011). In field studies during the 1980 s and 90 s, Ostrom observed how various common goods, particularly common-pool resources such as forests, rivers and water basins, had managed to survive for centuries due to collective action institutions of civil society managed by their own agents without coercion or external control (Ostrom, 1986, 1990; Ostrom et al., 1994). It does not, therefore, seem to be true that the solution for the efficient and sustainable management of common goods or resources lies in turning them into private or public property as Hardin suggested. According to Herbert A. Simon (1955), Ostrom's studies demonstrated that the time available and the cognitive and emotional capacities of the agents in the relationship had a determining role in rational decision-making processes (Ostrom, 1991, 1998a;). Unselfish cooperation was both possible and necessary to manage a society's common good (Ostrom, 1994).

The possibility that people can cooperate to meet common objectives in ways that are not merely driven by self interest has been supported in the neurosciences over the last decade. Neuroscientific studies have shown that, a) the neurological bases of human cooperation are not related to selfishness and the pleasure of reward, but to reciprocity and human altruism; b) the emotion afforded by the possibility of relating to others has a cognitive basis that, in many cases, is linked to experiences bound up with moral judgements on whether a behaviour or decision is just or unjust; and c) people will punish behaviours that violate the social and moral norms even if by doing so their own personal gain may be depleted ${ }^{1}$ (Glimcher et al., 2009). Thus, these and other conclusions from the neurosciences reveal the inconsistency of the perfect and complete rationality on which Hardin grounded the presumed tragedy of the commons, and shows the real possibility of people interrelating and questioning in order to meet objectives that are increasingly complex and beneficial for those involved in an optimum, sustainable and efficient way because of their emotional, communicative and critical competences (Tomasello, 2008, 2014b).

Evolutionary anthropology has also expressed similar ideas in recent years, through the understanding that the key factor in the development of all relational processes that are highly beneficial to all parties lies in people's capacities to specify and implement common projects in which the me perspective is abandoned in favour of the $u s$ perspective to generate rules and

1 Altruistic punishment is considered as a type of common good or resource (Tomasello, 2008, 2014a) 
usage norms with which to coordinate their actions, and to commit to active respect for the agreements reached (Tomasello, 2008, 2014b), all of which derives from an emotional, relational, communicative and critical rationality that humans have developed through the evolutionary process.

Consequently, the efficient, sustainable and optimally beneficial management of a society' common goods or resources is possible, and occurs by strengthening - not excluding, restricting or regulating- civil society participation by encouraging institutions for collective action as Ostrom's case studies in different countries so clearly showed (Ostrom, 1990, 1999a). Most states, however, continue to turn their backs on social movements in this sense, focusing their attention only on deciding between public and private management, even in cases of transnational commons with a universalisable interest such as air quality, public health care, conservation of biodiversity, defence of human rights or the management of scientific knowledge, among many others. In other words, a contradiction arises when the main parties involved and/or affected are excluded from their management because of their supposed incapacity to do so.

An outstanding example in this vein is the Svalbard Global Seed Vault (sGSv), located in Longyearbyen, Norway, promoted by the Norwegian government and funded by various states and international foundations. The main aim of the SGSV is to conserve biodiversity and guarantee food security for future generations against the threat of climate change. Paradoxically, while the states behind this initiative, on the one hand, put their efforts into managing this common good for the benefit of all humanity, they do nothing, or very little, to control internal production of genetically modified foods or to eradicate the high levels of unsustainable pollution caused by the GM industry, which are precisely two direct causes of the need for a Global Seed Vault in the first place, issues that are a direct challenge to the meaning of the initiative.

Another particularly relevant case is that of biological resource centres (BRCs), also known as biobanks, which in Spain are defined in Law 14/2007, of 3 July, on Biomedical Research as a "public or private non-profit establishment which has a collection of biological samples conceived for biomedical diagnostic or research purposes and organised as a technical unit with criteria of quality, order and destination» (2007: 28830). Hence, they are considered as a common good or resource whose management Spanish law leaves in the hands of public and private centres so long as they are not-forprofit organisations, thereby side-lining, or even restricting, possible civil society initiatives through the creation of collective action institutions that could be more efficient and sustainable in the medium and long term. 
Allowing, but also encouraging and strengthening, active committed civil society participation in the management of these and other common goods or resources also calls for an adequate process to generate the legitimacy and credibility necessary to allow a specific activity to take place. For biobanks and, above all, the use of the information stored in them to be appropriate, proper channels of communication are required to promote transparency and engage in debate with society; in other words, in order to generate and strengthen society's trust in the good management of these information pools a mature public opinion must be fostered, and this emerges from civil society.

The creation of knowledge is, therefore, a common good or resource that needs civil society participation in order to be adequately generated and strengthened, especially when the questions at stake are of particular interest to those involved and/or affected by such studies, such as protecting data on the subjects of the research, determining future social policies or developing research areas and projects.

\section{CIVIL SOCIETY PARTICIPATION IN THE ETHICAL MANAGEMENT OF BIOBANKS}

The world of biobank or BRC research is interesting from the point of view of the common good, as it, from one perspective, so clearly starts out from a conception of our genes being a common resource -this in contrast to most other research. Article one of the Universal Declaration on the Human Genome and Human Rights states that the «human genome ..., in a symbolic sense, is the heritage of humanity». This has led many to object to the commercialisation of genetic research and its products, and, when it nevertheless is subject to intellectual property regimens, to put great emphasis on benefit-sharing (Dauda \& Dierickx 2013).

On the other hand, the world of medical research has been called «a lingering bastion of medical paternalism, an ivory tower left unquestioned for too long» (Johansson, 2014). This stems from a «failure to realize or acknowledge that patients possess and can add experiences and insights that medical professionals and other involved parties lack» (ibid). Civil society might, on the contrary, argue that with regard to biobanking it should also have a say in a) what projects are undertaken, b) how they are designed, c) conducted, and d) the results implemented among stakeholders and in society. Only then will a public good -biobanks owned by universities and hospitals- be used such as to make it more akin to a common good, i.e. something that self-organising communities collectively oversee and steer in order to 
preserve as a resource for themselves and for future patients. The more space for civil society to negotiate the production and use of samples and the information they potentially provide, the more biobanks turn into a common good.

Strictly speaking, it will seldom become one, as research is a public activity and distribution channels of science is primarily situated in the larger scientific community. This does neither imply the impossibility for it to have aspects of public and common goods simultaneously, nor for trying to strengthen its character as common. On the contrary, such a movement is already on its way -and in a sense, some forms of research trusts could potentially serve as fully developed collective action institutions. Moreover, as science is a universal undertaking, prone to crossing borders, participatory action in this sphere might manage a feat many proponents of common goods see as ideal -but which is very seldom realised- that of partaking in a global endeavor not restricted to national interests governed by states. In concrete terms: When networks of biobanks operate on a transnational basis, participatory action institutions might have an advantage -compared to national institutions- in being able to act with the same authority in such a setting as in a national one.

Involvement of the public in research is being developed in various directions today. One approach discussed herein is a "participant-centered»-or -led or -driven- one, which has been defined as "tools, programs and projects that empower participants to engage in the research process' using interactive information technology» (Kaye et al., 2012).A key feature of such approaches, they say, is that patients and participants are found at the center of decision making «as equal partners in the research process» (ibid), an idea that actually seems much stronger than just having people engage in research through the help of IT tools.

Instead of saying that such approaches are all participant-centered in the same sense or to the same degree one could speak of different levels of participatory strength in various initiatives. Many of the initiatives mentioned by Kaye et al. (2012) are simply using modern information technology to facilitate the recruitment of and communication with research participants without necessarily giving participants more of a voice or power in the actual research being conducted. This would constitute a weak model of participation -one similar to the traditional model of participation, simply with more technological tools for recruitment and so on. If participants are given the resources and opportunity to, for example, manage their individual informed consent continuously or engage with each other -thus strengthening their participatory authority and the sense of community respectively-, we could talk of a moderate model of participation. A model that empowers 
participants to collectively act in order to drive either a) what projects are undertaken, b) how they are designed, c) conducted, or d) the results implemented among stakeholders and in society, or a combination thereof, would make a strong model of participation.

Examples of moderate or PCI models already exist. Kaye et al. listed the following a few years ago: PatientsLikeMe,TuAnalyze, and Genomera, all from the USA, and Genomes Unzipped from the un (Kaye et al., 2012). These are not considered strong models of participation, as put forth in this article, because they are still mainly based on the "need to place the individual at the centre of decision making» (ibid, our italics). Another recent example of an initiative that seems keen to engage citizens primarily to educate them and to gain acceptance for policy is the Consensus research project (http:// www.consensus-project.eu/).Yet other examples of engagement are 23andMe (Vayena \& Tasioulas, 2013), the U.S. Patient-Centered Outcomes Research Institute (Johansson, 2014), and the muscular dystrophy patients that engaged greatly in research (Callon \& Rabeharisoa 2008). As biobanking has turned out to be expensive -both Genizon in Quebec, Canada and decode Genetics in Iceland have gone bankrupt-, it is not surprising that biobanks have searched widely for economic support, also from charities and the like (Caulfield et al., 2014).

A strong model of participation could have numerous advantages in furthering science -lowering costs, promoting recruitment, lowering drop-out, promoting clinical applications, etc. (Nielsen, 2012). Such benefits are nevertheless not necessarily linked to such a model; it might as well fail in accomplishing the goods and another model, for example a moderate participatory one or one of industry partnerships, might do better in practice. But the most important gain from the perspective of this paper would be that a strong participatory model could strengthen democratic involvement and the civic society's opportunities for making the research endeavor also theirs, so that public engagement in someone else's project is ultimately turned into collective civic action - a good that is conceptually linked to such a model.

Such action would expand on the possible futures in which the uses of science and technology uphold, transform, and re-imagine the ways we live, and not just accept at face value the demands for competitiveness, development, and economic growth coming more and more often from policy makers, industry and academia - who do share a common managerial logic which results in such objectives being dominate (Science in Society, 2012).

What are the risks with this aspirational vision? One is of course that what would first pass for strong participatory engagement in fact is nothing more than a more elaborate way of pushing people to where the researchers 
-or funders of research- want them to be. Another is that the participant group seldom is homogenous. Thus a research endeavor might result in conflicts where one group decides for another or the research never even becomes feasible. ${ }^{2}$ These risks are real and strategies need to be developed in order to minimize them; but, they aren't objections to the vision itself. Such objections are rather of a political-economic nature where other values than those above are given precedence -liberal ideas of research autonomy or the need for economic development etc. Ultimately, whether we should strive for strong participatory action -as defined herein- in biobank research is a question of what kind of society we wish to live in and what we take to be the fundamental values of that society.

Of particular interest is the fact that institutionalised biobanks, often set up as non-profit entities or organisations, might have to turn to commercialisation strategies to secure their continued existence and to comply with funders' wishes for utility and societal applications (Caulfield et al., 2014). We do know that commercialization is a major issue for sample providers/ participants (ibid); participatory action would in such a situation enable them to not only address the question whether to actually engage in a public-private partnership, but also to affect the very terms of this relationship. For example, if participants fear losing control over how their samples and data are used by the biobank and those utilising it, having representatives who participate in the decision-making -and having the opportunity to do so oneself- could be that which makes the activities acceptable or even trustworthy in the eyes of participants.

If, ultimately, a choice is made in favour of civil society participation, much remains to be worked through. Familiar notions of risk and ethical considerations, such as conflict of interests, exploitation and the therapeutic misconception, might be exacerbated in some participatory research. Research ethics and regulations are individual-centered -both with regard to e.g. consent and to protection of data- and thus ill-equipped to deal with this novel phenomenon which includes collective action and strongly promotes sharing sensitive data. Not to mention that they still are predominantly national and sectional in nature and thus might lack the means to oversee initiatives crossing national or institutional borders. Research projects may even fall outside the scope of the usual oversight mechanisms, as they might lack state recognition and an institutional dimension Vayena \& Tasioulas, 2013). Ownership and decision rights over samples and data are still contested issues. The question of who legitimately can act as a representative of others is another difficult one. The researchers might interpret

2 See Schuklenk \& Kleinsmidt, 2006, for some examples on these. 
calls for participatory engagement as an infringement on their autonomy and skill, and as an obstacle to do good research, so there's a need to think more deeply about the division of roles in cooperative research and the forms for decision-making that could be implemented.

As have been pointed out by European Scientific Review Groups, a large body of research has shown that 'science' and 'society' are not «clearly delimited or predefined entities" but "fluid and take shape in heterogeneous, context-specific forms». Therefore, participatory action and other forms of public engagement «represent locations (or spaces) where values and norms and thus power relations are negotiated» (Science in Society, 2012). This means that ethical debate and regulatory advances in this field must be an on-going effort which will never be completed; as long as our societies are in "continuous transformation" (ibid), the myriad ways that participatory action can be reframed will make the need for again thinking through its goals and forms of operation ever present, ever new.

To begin to do this, we need to learn more about present initiatives: how they are set up, how they function and whether they succeed in realizing both scientific and participatory ends. This issue of Recerca. Revista de Pensament $i$ Anàlisi serves as a general starting point for discussing such issues and stimulating further exploration into the subject. ${ }^{3}$

\section{BIBLIOGRAPHY}

Bowles, S. and GinTIS, H. (2011): A Cooperative Species. Human Reciprocity and its Evolution, Princeton, Princeton University Press.

Callon, M. and Rabeharisoa, V. (2008): «The Growing Engagement of Emergent Concerned Groups in Political and Economic Life. Lessons from the French Association of Neuromuscular Disease", Science, Technology \& Human Values, 33 (2), 230-261.

Cárdenas, J.C. and Ostrom, E. (2004): «What do People Bring into the Game? Experiments in the Field about Cooperation in the Commons", Agricultural Systems, 82, 307-326.

Caulfield, T. et al. (2014): "A Review of the Key Issues Associated with the Commercialization of Biobanks», Journal of Law and the Biosciences, 94-110. [Dor: 10.1093/jlb/lst004].

Dauda, B. and Dierickx, K. (2013): «Benefit Sharing: An Exploration on the Contextual Discourse of a Changing Concept», BMC Medical Ethics, 14:36. [DOI: 10.1186/1472-6939-14-36].

3 The authors would like to thank Heidi Howard for her help in preparing this article. 
FEHR, E. et al. (2002): «Strong Reciprocity, Human Cooperation and the Enforcement of Social Norms», Human Nature, 13 (1), 1-25.

GINTIS, H. et al. (eds.) (2005): Moral Sentiments and Material Interests. On the Foundations of Cooperation in Economic Life, Cambridge, Мाт Press.

Gumcher, P.W. et al. (eds.) (2009): Neuroeconomics. Decision Making and the Brain, Amsterdam, Elsevier Academic Press.

Hardin, G. (1968): «The Tragedy of the Commons», Science, 162 (1), 12431248.

JEFATURA DEL EsTADO (2007): «Ley 14/2007, de 3 de julio, de Investigación biomédica», Boletín Oficial del Estado, 159, pp. 28826-28846. Retrieved from http://www.isciii.es/ISCIII/es/contenidos/fdinvestigacion/Ley_Investigacion_Biomedica.pdf.

Johansson, V. (2014): «From Subjects to Experts-On the Current Transition of Patient Participation in Research», American Journal of Bioethics, 14 (6), 29-31.

KAY, J. et al. (2012): «From Patients to Partners: Participant-Centric Initiatives in Biomedical Research», Nature Reviews Genetics, 13 (5), 371-376.

Nash, J.F. (1950a): «Equilibrium Points in n-Person Games», Proceedings of the National Academy of the United States of America, 36 (1), 48-49.

- (1950b): «The Bargaining Problem», Econometrica, 18 (2), 155-162.

Nielsen, M. (2012): Reinventing Discovery: The New Era of Networked Science, Princeton: Princeton University Press.

Ostrom, E. (1986): «An Agenda for the Study of Institutions», Public Choice, 48 (1), 3-25.

- (1990): Governing the Commons:The Evolution of Institutions for Collective Action, New York, Cambridge University Press.

- (1991): «Rational Choice Theory and Institutional Analysis: Toward Complementarity», American Political Science Review, 85 (19), 237-243.

- (1994): «Constituting Social Capital and Collective Action», Journal and Theoretical Politics, 6 (4), 527-562.

- (1998a): «A Behavioral Approach to the Rational Choice Theory of Collective Action», American Political Science Review, 92 (1), 1-22.

- (1998b): «Self-Governance of Common-Pool Resources» in Newman, P. (comp.): The New Palgrave Dictionary of Economics and the Law. Vol. 3, London, Macmillan Press, 424-433.

- (1999a): «Design Principles and Threats to Sustainable Organizations that Manage Commons», Center for the Study of Institutions, Population, and Environmental Change, 1-16. Retrieved from http://dlc.dlib.indiana.edu/dlc/bitstream/handle/10535/5465/Design\%20Principles\%20 
and\%20Threats\%20to\%20Sustainable\%20Organizations\%20That\%20Manage $\% 20$ Commons.pdf? sequence $=1$.

- (2003): "Toward a Behavioral Theory Linking Trust, Reciprocity, and Reputation» in Ostrom, E. and Walker, J. (eds.) (2003): Trust E Reciprocity. Interdisciplinary Lessons from Experimental Research, New York, Russell Sage Foundation, 19-79.

Ostrom, E. and Nagendra, H. (2010): «Governing the Commons in the New Millennium: A Diversity of Institutions for Natural Resource Management» in Rudy, I. and Ruby, A. (eds.): Re-Inventing Construction, Berlin, Rudy Press, 380-87.

Ostrom, E., et al. (1994): Rules, Games, and Common-Pool Resources, Ann Arbor, University of Michigan Press.

Ostrom, E. et al. (eds.) (2002): The Drama of the Commons, Washington D.C., National Academy Press.

Ostrom, E. and Ostrom, V. (2011): «The Institutional Perspective on Values and Virtues» in DE VRIES, M. and KIM, P.S. (eds.): Value and Virtue in Public Administration:A Comparative Perspective, New York, Palgrave Macmillan, 115-134.

SCHUKLENK, U. and KleInSmidt,A. (2006): «North-South Benefit Sharing Arrangements in Bioprospecting and Genetic Research: A Critical Ethical and Legal Analysis», Developing World Bioetbics, 6 (3), 122-34.

SCIENCE IN Society: CARING FOR OUR FUtURES IN tURbULENT tIMES. Science Policy Briefing no 50, June 2013, European Science Foundation.

SImon, H.A. (1955): «Behavioral Model of Rational Choice», The Quarterly Journal of Economics, 69 (1), 99-118.

Tomasello, M. (2008): ¿Por qué cooperamos?, Madrid, Katz,

- (2014a): A Natural History of Human Thinking, Cambridge, Massachusetts, Harvard University Press.

- (2014b): «The ultra-social animal», European Journal of Social Psychology, 44, 187-194.

Vayena, E. and Tasioulas, J. (2013): «Adapting Standards: Ethical Oversight of Participant-Led Health Research», PLoS Medicine, 10 (3), E1001402. [DOI: 10.1371/JOURNAL.PMED.1001402].

Westengen, O.T. et al. (2013): «Global Ex-Situ Crop Diversity Conservation and the Svalbard Global Seed Vault: Assessing the Current Status», PLoS ONE, 8 (5), e64146, pp. 1-10. Retrieved from http://www.plosone.org/ article/fetchObject.action?uri=info\%3Adoi\%2F10.1371\%2Fjournal.pone. 0064146\&representation=PDF. 